УДК 316.4.066

DOI https://doi.org/10.32840/2707-9147.2020.86.8

I. О. МАРТИНЮК

доктор соціологічних наук, старший науковий співробітник, провідний науковий співробітник відділу соціальної психології Інститут соціології Національної академії наук України

Н. І. СОБОЛЕВА

доктор соціологічних наук, старший науковий співробітник, провідний науковий співробітник відділу соціальної психології Інститут соціології Національної академії наук України

\title{
СОЦІАЛЬНІ ЗМІНИ ТА АГЕНТИ ЗМІН У СУЧАСНОМУ СВІТІ: СОЦІОЛОГІЧНІ РЕФЛЕКСІЇ
}

Статтю присвячено проблемі концептуалізачіі соціальної агентності в сучасному світі, визначенню теоретичних координат сочіологічного дослідження агентів сочіальних змін. Обтрунтовано актуальність розроблення проблематики агентності, проаналізовано особливості реалізації ї̈ різних форм в умовах бурхливих сочіальних трансформацій і пошуків ефективних шляхів досягнення соиіального балансу. Розглянуто презентації иієї проблематики в сучасному соиіологічному дискурсі, зокрема вітчизняному. Зафіксовано певні розбіжності в концеепууалізаціях поняття «агентність» представлених у різних соціологічних напрямах та відсутність якоюсь мірою усталених й узгоджених теоретичних висновків щуодо наукового визначення сочіальної агентності.

Зафіксовано певні розбіжності в кониептуалізаціях поняття «агентність» представників різних сочіологічних напрямів та відсутність порівняно усталених й узгоджених теоретичних висновків щодо наукового визначення сочіальної агентності. На основі теоретичного обтрунтування поняття «сочіальний агент» визначено ключові функиіі та характерні ознаки агентів змін із позииій діяльнісних параметрів. Поворот соціологічної теорії вбік побудови моделей потрактування чинників практичної життєдіяльності в межах повсякденної рутинної взаємодії сочіальних акторів різного рівня позначив новий ракурс підходу до виявлення різноманітних поєднань динамічних складників сочіального життя як його формоутворюючих обставин і умов.

Наголошено на важливості в агентних діях як окремих індивідів, так $і$ груп, страт, організацій та інших спільнот саме практик, спрямованих на реалізацію чи принаймні полегшення досягнення сочіальних змін. 3'ясовано, щзо практика як сочіальний зміст, своєрідний стрижень багатосторонньої й багаторівневої суб'єкт-суб'єктної взаємодї, яка в соціальних реаліях проявляється в різноманітті поведінкових форм, $\epsilon$ втіленням, $з$ одного боку, усталених культурою ціннісно-нормативних елементів, статусно-рольових особливостей вибору й застосування поведінкових патернів, з іншого - габітуальних напрацювань актора, відо-

(C) I. О. Мартинюк, Н. І. Соболєва, 2020 
браженням його мотиваційної архітектоніки. Сполучення суспільних й індивідуальних особливостей у структурі практики є одним із «перехресть», на якому відбувається взаємопроникнення усталеного й відмінного від нього інновачійного.

Ключові слова: сочіальний розвиток, сочіальні зміни, агенти змін, агенти впливу, практики соччіальної взаємодіï.

Постановка проблеми. Особливої актуальності темі ролі агентів змін у сучасному світі надає поворот у соціологічному теоретизуванні від проблематики суб'єктності до проблематики агентності, від дослідження соціальних дій до дослідження відповідних соціальних практик. Агентом змін (від лат. agens, рід. відмінок agentis - діючий) прийнято позначати соціального актора, учасника ситуації, здатного безпосередніми діями контролювати ситуацію й регулювати розвиток подій в тому чи іншому напрямі.

Мета статті. Головною метою цієї роботи є проаналізувати соціологічні рефлексії соціальних змін та агентів змін у сучасному світі.

Виклад основного матеріалу. Об'єктом соціальних змін можуть бути соціальний устрій суспільства і сформовані соціальні порядки в ньому, нормативне регулювання та стереотипи соціальної поведінки. Предметний зміст соціальних змін становить поступальний (найчастіше) розвиток суспільства і своєчасна зміна його суспільно-формаційної композиції, спрямована модифікація соціальної організації суспільства і його соціальних інститутів відповідно до викликів часу, формування інновацій у різних соціальних системах і зростання різноманіття інституціональних і неінституціональних форм прояву активності й різновидів соціально схвалюваних поведінкових практик.

Показово, що серед творів жанру сайенс фікшн, у яких так чи так розглядалась тема соціальних змін та їх, так би мовити, «здійснювачів», певна частина помітно тяжіє до сайенс, ніж до фікшн. До золотого фонду таких творів, поза сумнівом, належить роман А. Азімова «Кінець вічності». За фабулою, людство створило «машину часу» й наклало найсуворіші обмеження на іï використання, щоб уникнути «ефекту метелика». Право й обов'язок застосування винаходу передані могутній організації під урочистою назвою Вічність, що охоплює величезну армію Спостерігачів, Статистиків, Соціологів, Зв’язківців, Інженерів, Розрахувальників i, нарешті, виконавців - Техніків, які безпосередньо здійснюють Мінімально Припустиме Втручання (МПВ), змінюючи історію й долі мільярдів людей. Здавалось, усе передбачено, окрім найголовнішого - принципової неможливості прорахувати стратегічні негативні наслідки ухвалених рішень. Сама спроба створити ідеально досконалий регулюючий механізм приречена, оскільки із часом змінюються цінності, котрі лежать у підгрунті тієї чи тієї цивілізації. Якщо користуватись масштабом історичних епох, то неминуче відбуваються трансформації норм, значень і смислів, що видавались вічними. До речі, така плинність породжує запитання: чи можливі взагалі загально- 
людські цінності. Для якогось періоду, відтинку історії - так, у зв’язку, зокрема, з необхідністю вирішити масштабне історичне завдання, принципово - навряд. (Візьмемо, наприклад, питання цінності життя vs евтаназії як права припинити його за свідомим бажанням її суб'єкта, або інше - дискусію щодо того, чи є людина найвищою цінністю, як це стверджується в гуманістично орієнтованих концепціях, чи варто розглядати іiі лише як етап розвитку розуму).

Пізніше міркування А. Азімова набули теоретичної бази у вигляді концепції ризику У. Бека та його послідовників. У міру ускладнення технологій і збільшення масштабів їхнього застосування зростає вірогідність технологічних помилок. У зону ризиків потрапляють не лише окремі індивіди, а й суспільство як таке, причому в різних сферах сучасного життя (інституційній, економічній, соціально-економічній, соціальній, політичній тощо) ризики породжуються систематичною взаємодією людської спільноти 3 модернізованим глобальним виробництвом.

Проблема незворотності генерації ризиків у міру модернізації суспільства вирішується у площині ії часткового, парціального розв'язання, внаслідок чого боротьба 3 ризиками зазвичай зводиться до звуження «сектору обстрілу», тобто обмеження можливостей утілення загроз і небезпек у життєві реалії. Так само агенти соціальних змін, якими б теоретичними концептами вони не керувались у своїх діях, найчастіше не можуть визначити віддалені, а часом і безпосередні наслідки своїх учинків, які бувають і зовсім протилежними тому, що замислювалось спочатку (згадаймо рядки Й-В. фон Гете: «Я тої сили частка, що робить лиш добро, бажаючи лиш злого», або славнозвісне «благими намірами< $<.>$ »).

Крилатий вислів російського експрем'єр-міністра В. Черномирдіна: «Хотіли як краще, а вийшло як завжди», - якщо полишити осторонь іронічний відтінок, наголошує на принциповій неможливості досягти доступними нам засобами (прогнозування, стратегічного планування, регулювання, нарешті практичного втілення ) навіть не приблизного ідеалу, а принаймні чогось схожого. Думка не є абсолютно новою iii інваріанти розкидані в історії філософії і практиці пізнання. Отже, ефект «історичного відлуння», поза сумнівом, підлягає вивченню, але не може бути вивченим повністю й остаточно.

Цілком переконливою виглядає ідея К. Маркса про природноісторичний характер суспільного розвитку, що відтворена у вигляді паралелограма сил. Однак ця двовимірна модель, прогресивна для свого часу, демонструє лише загальний принцип взаємодії воль окремих соціальних суб'єктів. Зокрема, залишається поза межами осмислення характер цілеспрямованих дій, закладений у навколишньому світі культури («Соціологія одних дверей» Б. Латура). Загалом же $\mathrm{N}$-мірне сполучення воль і прагнень колективних та індивідуальних акторів втілюється в найскладніший архітектониці сучасних суспіль- 
них відносин, і часом задосить «камінця 3 гори» для здійснення радикальних трансформацій, а іноді залишаються безрезультатними потужні зусилля впливових агентів (свіжий приклад - парадоксальний успіх на президентських виборах «команди Зе» всупереч потужному адмінресурсу й реальним реформаторським напрацюванням адміністрації П. Порошенко). Тобто суспільний розвиток і кардинальні зміни в суспільстві підпорядковуються набагато складнішим закономірностям, ніж славнозвісний «паралелограм сил».

Відома вітчизняна соціологиня О. Злобіна, виступаючи модератором Круглого стола «Агенти соціальних змін у суспільстві нестійкої інституціональності: особистості, ідеї, соціальні рухи», зорганізованого відділом соціальної психології Інституту соціології НАНУ, котрий відбувся в Інституті соціології НАН України 3 грудня 2019 року й був присвячений 95-літтю фундаторки відділу соціальної психології Інституту соціології НАН України - Лідії Василівни Сохань, зазначила, що проблема агентності належить до найбільш теоретично запитуваних та активно обговорюваних у сучасній соціології. В дискусії щодо агентності, яка точиться навколо відомої дихотомії Е. Гіденса щодо агентності та структури, взяли участь практично всі важковаговики соціологічного метатеоретизування. Дж. Александер, М. Арчер, 3. Бауман, П. Блау, П. Бурдьє, Ю. Габермас, Дж. Коулмен, Д. Норт, Дж. Ритцер, П. Штомпка і ціла низка інших фахівців не оминули цю проблему у своїй науковій творчості і взяли участь у науковому дискурсі щодо агентності, так чи інакше зачіпаючи цю тему у своїх працях. Однак певною мірою усталених теоретичних висновків здійснений дискурсивний аналіз не приніс.

Пошук у цьому напрямі триває, як свідчать результати теоретичного осмислення стану та перспектив соціологічних розвідок [2]. Не залишається осторонь і вітчизняне суспільствознавство. Щоправда, тут так само немає єдності в поглядах; обгрунтування визначень спирається на ту чи ту парадигмальну настанову, без викладу якої теоретичні напрацювання видаються сумнівними. Наприклад, Л. Бевзенко пропонує рухатись шляхом залучення до концептуалізації парадигми складності, поєднуючи іiі з мережевою та практичними теоріями. На такому еклектичному підгрунті вибудовується інтегративна концепція соціальної напруженості [1], від якої, на думку авторки, можна перейти до інституціональної нестабільності, й далі - до тлумачення агентності як відповіді на міру напруженості. Тому, наприклад, для теоретичного розуміння запропонованого Л. Бевзенко поняття «радіус агентності» потрібно розібратись із діапазонами (вони ж «рівні») напруженості, чому їх три (а не шість, скажімо), що зумовлює «нелінійний характер» їхньої сполученості тощо.

Є певні розбіжності в концептуалізації поняття «агентність» і між авторами цього допису. Н. Соболева розглядає соціальні зміни як перехід того чи іншого елемента соціальної системи або цілої системи 3 
одного агрегатного стану в інший, з однієї стадії розвитку в іншу, трансформації, котрі відбуваються в соціальних спільнотах, групах, інститутах упродовж деякого часу. Водночас відмінності між колишнім i нинішнім станом будь-якого соціального об’єкта стають помітними настільки, що можна говорити про зміну міри, що фіксує якісну визначеність такого стану. Вони можуть здійснюватись на рівні міжособистісних відносин; малих і великих соціальних груп; соціальних організацій та інститутів; суспільства й соціуму загалом. Агент змін - це ініціатор, суб'єкт дії та відповідальний виконавець водночас, байдуже чи то індивідуальний, чи то колективний актор. Це активний, наділений свідомістю й волею безпосередній учасник ситуації, котрий витрачає у процесі дії власну енергію та ресурси й несе відповідальність за результати своєї активності.

Агентами змін можуть бути персони (окремі індивіди), колективи, спільноти та співтовариства, різні соціальні групи, інституціоналізовані та неінституціоналізовані організації та структури, громадські рухи, головне заняття яких полягає в підтримці та контролі процесу перетворень. Таким чином, агенти змін - це індивідуальні й колективні актори, соціально активні суб'єкти різного рівня компетенції та спеціалізації, які є провідниками місій, цінностей, стратегій, цілей і принципів стабільного функціонування та розвитку суспільства й підтримання соціального порядку в ньому, тобто це такі собі «соціальні експерти», які мають власне бачення щодо стратегічних і ситуативних проблем розвитку суспільства і пропонують практичні рішення з розв'язання цих проблем, а також безпосередньо залучаються у процес реалізації соціальних змін.

На відміну від агента змін, агент впливу - це суб'єкт-актор, який сприяє соціальним змінам, діє в інтересах суб'єктів, котрі безпосередньо стимулюють та реалізують зміни, бере непряму участь у координації перетворень. Форми й масштаб активності та ступінь відповідальності в агентів впливу якісно відрізняються від активізму агентів змін.

Агент впливу - суб'єкт, який здійснює поширення своїх ідей або ідей іншої людини, організації, партії в середовищі людей, які не $\epsilon$ адептами цих поглядів і не належать до цієї організації чи партії. Активність агента впливу спрямована не саме на зміни, а на зміну поглядів, орієнтацій колег, послідовників, слухачів, споживачів iз тим, щоб вони природним чином схилялись до лобійованих їм позицій та відповідних рішень щодо втілення цих ідей у практичній діяльності неофітів.

На відміну від Н. Соболевої, яка наголошує на активності й відповідальності у ставленні до змін, що відбуваються, як основних ознаках агентності, I. Мартинюк звертає увагу на численність механізмів соціальних змін. Сюди, наприклад, відносяться практики, конфлікти, напруженість, еволюція, революція, інновація тощо. Багатоморфність механізмів актуалізує питання не лише про численність типів агентів 
змін (їхній опис представлений досить виразно в попередній концепціiі), а про зіставлення результативності тих чи тих агентів, поки навіть не заторкуючи вірогідну диференціацію, залежно від полей використання їхніх зусиль. Загальне питання полягає в тому, чи сприяють їх дії якимось чином зміні соціальних обставин чи виявляються марними ? (Полишимо історикам побудову версій чому так сталось - унаслідок передчасності чи некомпетентності дій, зайвого завзяття чи нерішучості «кандидатів в агенти змін» чи безлічі інших, незалежних від них обставин). Занурюючись в аналіз того унікального збігу обставин, конфігурації умов і чинників, за яких і яким чином спрацював механізм соціальної зміни, ми уподібнимось до преферансистів, які, записуючи дошкульний результат, обгрунтовано доводять, що «цей мізер не міг бути зіграний». Важливою для оцінки агентності є те, чи відбулась соціальна зміна (нехай навіть неочікувана - «хотіли як краще <...>») чи ні. Тобто агентність дій соціального суб'єкта можна оцінити лише постфактум, антиципація ж наслідків дій соціального суб'єкта завжди будуватиметься на хиткому фундаменті стохастики.

Незалежно від нюансів тлумачення «агентності» як такої, агент (принаймні, той, кого ми таким вважаємо) як дійовий суб’єкт виходить iз певної картини світу, свого місця в ньому, сформованих уявлень про «значущих інших», габітуальних навичок, певним чином інтерпретує свою історію, наміри, мотиви й конструює образ майбутнього. Водночас кращі шанси переважно набуває той гравець, який удається до максимізації ресурсів, раціональніше використовує їх та активно впливає на формування «правил гри», хоч усе це не гарантує досягнення остаточного успіху. За всім цим стоїть багато складників формальні й неформальні соціальні норми, переконання й установки, корпоративна та індивідуальна культура, відображення цінностей у свідомості окремих індивідів або ж у культурах суспільств, товариств та організацій.

До основних функцій агентів змін, на нашу думку, належать:

- продукування головних стратегічних завдань, адекватних цінностям агентів змін і смислів (значень) соціального розвитку;

- організація процесів перетворень та контроль за ними;

- залучення різних верств до безпосередньої участі у процесах, що завдяки здійсненню накреслених завдань мають привести до бажаних змін;

- інформаційне забезпечення, трансляція необхідних знань, створення освітніх засад сприйняття змін шляхом навчання відповідним навичкам, необхідним у нових ситуаціях;

- пропагандистське сприяння змінам, що відбуваються, роз'яснення їх причин та особливостей.

Перелік цих функцій навряд чи варто вважати остаточним; наразі автори допису не ставили собі за мету якомога повніше, детальніше розкрити функціональне навантаження, пов'язане 3 діяльністю аген- 
тів змін. Ідеться про те, що на підставі змалювання основних функцій, які, безумовно, можуть бути відображені рельєфніше, чіткіше, спробувати визначити характерні ознаки агентів змін із позицій діяльнісних параметрів.

У виступі на вже згадуваному круглому столі О. Злобіна зазначала, що, на іï думку, серед ключових показників, котрі характеризуватимуть особливості особистісного залучення до агентності, мають бути виокремлені такі: агенти залученості (люди, ідеї, групи, рухи); стимули участі (очікувані особистісні та суспільні зиски); роль соціальних атракторів у розгортанні агентності; особистісні зміни та здобутки. Загалом погоджуючись із їі висновком про те, що сучасна лінія дослідження агентності тісно пов'язана із соціально-психологічними дослідженнями, ми все ж дещо інакше бачимо сукупність ознак, котрі властиві агентові змін.

На наш погляд, є три типових елементи, які характеризують агента змін. Зупинимось на них докладніше.

Здійснення будь-якої планомірної свідомої діяльності, яка не $\epsilon$ рутинною, репродуктивною хоча б почасти. Краще за все це положення ілюструє відома притча про будівництво Шартрського собору. Перехожий запитав по черзі кількох будівельників про те, що вони роблять. «Тягаю це кляте каміння», - відповів один. «Заробляю на кусень хліба», - мовив другий. «Будую Шартрський собор», - гордовито сказав третій. Як бачимо, за умов однієї й тієї ж діяльності можливі різні варіанти самоідентифікації іiі суб'єктів. Найцікавіше, що за трудовим унеском досягнення останнього будівельника можуть виявитись найскромнішими, але 3 погляду смислів саме його можна вважати агентом змін, бо для нього характерно «бачити за деревами ліс». 3 іншого боку, надлишок «теоретиків необхідних змін» загрожує тим, що без практичних дій зміни ніколи не відбудуться. Тому у словосполученні «планомірна свідома діяльність» значущість останнього слова аж ніяк не остання.

Дії в межах певної ситуації (реальної або принаймні визнаної такою актором). Ідеться про умови й чинники, їхню конфігурацію, що склалась у цьому хронотопі, структуру, особливості їх поєднання та взаємодії, тривалості, інтенсивності й послідовності впливу тощо. А головне - те, що ситуація є породженням суб'єктивної соціальної реальності, не виникає сама собою, незалежно від якостей актора, a $є$ результатом міри і глибини освоєння об'єктивних умов (ресурсів), мотивованості, готовності і здатності суб'єкта ситуації діяти за нових умов. Використання ситуації найефективнішим чином $\epsilon$, на наш погляд, чи не визначальною рисою, котра властива агентові соціальних змін. Здатність останнього до ініціації й подальшої підтримки трансформацій суспільного життя визначається не елітним статусом та зумовленими ним ресурсними можливостями, а спроможністю розпоряджатися тим що $є$, насамперед осягненням потенціалу інститутів та харизмою у ставленні до їх перетворення. 
Варто також наголосити на «соціальній лабільності» - калейдоскопічному динамізмі ситуацій та їх масштабі. Констеляція чинників перебуває у стані перманентної мінливості й оцінюється акторами з різних позицій. Ця оцінка значно залежить від стану й навіть настрою суб'єкта (згадаймо «нежить Наполеона» під Ватерлоо), що лише приблизно передає формула «мінливе в мінливому». Отже, високий рівень адаптаційної готовності, вміння опанувати ситуацію, що змінюється (часом несподівано й докорінно), повернути обставини на свою користь $\epsilon$ необхідною ознакою агента змін. Водночас ідеться не про безхребетність, цинічне пристосуванство, а про вірність кінцевій передбачуваній меті. (Як сказав поет: «Та нехай собі як знають, божеволіють, конають, - а нам своє робить!»).

Щодо масштабності осмислення ситуації, то важливо брати до уваги те, що $є$ чинники, які ніби безпосередньо не впливають на неї, але насправді «задають» загальні обриси дій. Так, інституційна несталість, розхитаність сучасного українського суспільства зумовлює ослаблення впливу нормативних регуляторів, що, з одного боку, розширює простір соціальної творчості, підносячи значущість індивідуального актора, а з іншого відбирає в нього час та енергію на вирішення стереотипних завдань. Такі реалії часів розбудови незалежного українського суспільства накладають свій відбиток на характерні способи пошуку життєвих рішень, що різним чином впливають на «потенційних кандидатів в агенти змін».

Нарешті показовою ілюстрацією щодо глобальних наслідків різкої зміни ситуації, яка змінила звичний плин життя на всій планеті, $є$ вплив чинника коронавірусу на порівняно усталений спосіб життя. Жодні попередні успіхи, належність до еліт, статусні преференції тощо виявились нездатними нівелювати вплив і масштаб дії цього фактору. Отже, обставини змінюються поза бажанням учасників ситуації, проте це не означає, що відповідні агенти змін залишаються незатребуваними й діють «поза грою».

3. Здобуття відгомону в соиіальному світі у вигляді зміни соціальних практик, які за всієї константності досить чутливо реагують на соціальні зміни. Останнім часом відбувається сходження поняття «соціальна практика» до рівня однієї із ключових соціологічних категорій, яка набуває трансформаційного змісту у плані спрямування дослідницької думки на розуміння ії як перетворення зусиль соціальних агентів у зміни у структурно-інституціональній площині через укорінення відповідних зрушень у світі повсякденності. Поворот соціологічної теорії убік побудови моделей потрактування чинників практичної життєдіяльності в межах повсякденної рутинної взаємодії соціальних акторів різного рівня позначив новий ракурс підходу до виявлення різноманітних поєднань динамічних складників соціального життя як його формоутворюючі обставини й умови.

Постаючи як соціальний зміст, своєрідного стрижня багатосторонньої й багаторівневої суб'єкт-суб'єктної взаємодії, що в соціаль- 
них реаліях виявляється в різноманітті поведінкових форм, практика $є$ втіленням, з одного боку, усталених культурою ціннісно-нормативних елементів, статусно-рольових особливостей вибору й застосування поведінкових патернів, з іншого - габітуальних напрацювань актора, відображенням його мотиваційної архітектоніки. Сполучення суспільних й індивідуальних особливостей у структурі практики є одним iз «перехресть», на якому відбувається взаємопроникнення усталеного й відмінного від нього, інноваційного.

Соціальні практики покликані спростити буденне життя, надати йому певної передбачуваності, предметної визначеності; навичок поводження, сформувати стереотипи мислення та дій, а сукупність закріплених у культурних формах реакцій на стандартні ситуації зумовлюють ритуалізацію й через неї легітимацію відповідних способів соціальної дії. Практики слугують джерелом комплементарностей, завдяки яким в умовах нестандартної ситуації в разі потреби «добудовується» поведінка.

Не менш важливим моментом в агентних діях $є$ роль практик як окремих індивідів, так і груп, страт, організацій та інших спільнот, спрямованих на реалізацію чи принаймні полегшення досягнення соціальних змін. Відкритим залишається питання про ступінь усвідомлення спрямованості дій і характеру соціальних зсувів самими агентами змін. Зауважимо, що процес дерутинізації є водночас процесом рутинізації нових практик, а зіткнення традиційних практик з інноваціями найчастіше передбачає конфронтацію їх носіїв, хоча й не обов'язково через конфліктні форми прямого протистояння, але з неодмінним використанням певного виду тиску.

Дискурс категорії соціальних практик виводить на перший план і проблему міри, й пошуку критерію, відповідно до якого можна констатувати перехід до нового стану інституціональної дійсності, що грунтується на реальних суспільних змінах, а не формальних перейменуваннях інститутів або перерозподілі їхніх функцій без підвищення ефективності як типовому способі втілення реформістського «зудіння». Розглядаючи питання агентських ознак стосовно сучасних українських реалій, важливо наголосити, що для транзитного суспільства типовим $\epsilon$ еклектичне, суперечливе переплетіння старого й нового. Але соціальні зрушення просто не можуть відбутись не отримавши певного резонансу у сфері повсякденних практик, саме тому реалізація зусиль агентів змін у світ практик має таке принципове значення.

Наостанок зупинимось на питанні про порядок настання змін. Почнемо з так званого «вертикального» розрізу. В контексті здійснюваних соціальних трансформацій потрібно відмітити долучення до класичної схеми «локальне-національне-інтернаціональне», властивій культурі модерного суспільства, параметру глобального, що характеризує сучасний постмодерний світ. Поліморфність сучасних соціальних практик не означає, що в кожній із них неодмінно присутні 
елементи кожного з указаних рівнів, але комбінації їх поєднань, які виникають унаслідок підключення чинника глобалізації, розширює спектр і доступність відповідних ресурсів для соціального конструювання. Зміст сучасних практик визначається не лише структурно-функціональними особливостями й не обмежується характеристиками властивостей взаємодіючих агентів чи культурним наповненням їх життєдіяльності, а й зумовлюється соціально-просторовою конфігурацією застосованих патернів. Сучасний світ, хочемо ми цього чи ні, став глобальним. Із часом процеси глобалізації поглиблюються, а глобальні виклики потребують глобальних відповідей, інтеграції зусиль у пошуку інноваційних рішень, нестандартних підходів до розв'язування загрозливих ситуацій із непередбачуваними наслідками для всього людства, як ось, наприклад, події, спричинені пандемією коронавірусу.

Важливим є питання про «горизонтальний» поділ, тобто сектор діяльності, зміни в якому ініціюють лавиноподібну реакцію в інших. Звичайно, можна побудувати умоглядну схему зв'язку спелеологічних технік із дитячим вихованням, однак насправді $\epsilon$, на наш погляд, низка своєрідних «зв’язок», зміни в яких унаслідок змін в інших наступають порівняно легше: наука й виробництво, культура й мистецтво, організація й управління тощо, на перетині яких вірогіднішим $\epsilon$ шанс на реальні зміни, а, отже, й можливість безпосередньо зіткнутись із діяльністю агентів змін.

Візьмемо, наприклад, науку й виробництво або, ширше, пізнання й бізнес. Сучасна наука не $є$ долею невеликої групи професійних мислителів, далеких від проблем повсякденного буття, зайнятих виключно розумінням таємниць світобудови й міркуваннями про «високі матеріï». Професія науковця стала масовою, а вчені беруть активну участь у суспільному житті, стаючи реальними агентами змін як державні діячі, парламентарі, члени урядів, перебуваючи у владних структуpax, у керівництві компаній, політичних партій тощо. Сьогодні наука проникає в усі сфери й системи життєдіяльності людини, створюючи нове середовище проживання й буття людини, перетворюючи і змінюючи не тільки техніку й технології виробництва, але й повсякденне життя. Методи і прийоми наукової діяльності, практики генерації нового знання, прогнозування розвитку процесів й результатів діяльності впроваджуються в інші сфери суспільного життя - політику, економіку (бізнес), освіту, навіть у стосунки.

Сьогодні питання взаємодії науки й бізнесу є особливо актуальним. Зростання масштабів і кількості наукових досліджень, починаючи із другої половини ХХ століття, дозволило не тільки розробити, але й довести до промислового впровадження якісно нові технології, створені на основі фундаментальних наукових розробок, і сформувати нові глобальні ринки товарів і послуг. Водночас виробництво багатьох нових видів продукції й послуг у таких сферах, як, наприклад, мобільний зв’язок, фармацевтика, «зелена енергетика», а остан- 
нім часом навіть космонавтика, все більше звільняється від державного регулювання й переходить у руки приватного бізнесу. Необхідний для втілення наукових результатів у конкретну продукцію час істотно скоротився, а сучасні засоби комунікації вдосконалилися настільки, що це дозволило бізнесу виключити з інноваційного ланцюжка різні посередницькі структури й вийти на прямі контакти з наукою, діючи у власних інтересах.

Ідеться не тільки про замовлення, але і про безпосереднє фінансування науки бізнесом. У розвинених країнах світу обсяг небюджетного фінансування науки у два рази перевищує бюджетне (державне), в той час як у бідних країнах і країнах, котрі розвиваються, низька затребуваність бізнесом наукових результатів гальмує розвиток не тільки самого бізнесу, а і країни загалом.

Що ж до бізнесу, то його багатоликість і різноплановість спричиняє деяку аморфність його визначення, яке в певному наближенні можна позначити як діяльність, спрямовану на систематичне отримання прибутку. Сфери бізнесу охоплюють переважну частину людського життя, поширюючись навіть на ті предмети, процеси і явища, що традиційно не включались до сфери бізнес-інтересів (науку, культурно-видовищні заходи, мистецтво, освіту, спорт, інформатизацію тощо). Бізнес відрізняється за масштабами (кількістю й обсягом виробленого, задіяними ресурсами, кількістю працівників, структурою), поділяючись на дрібний, середній і великий. Головними сферами бізнесу виступають виробництво, фінанси, торгівельно-комерційна діяльність, транспортні послуги, посередництво, страхування, засновані на інноваційних технологіях, інформатизація, зв'язок, низка інших галузей.

Не менш складною є внутрішня структура бізнес-діяльності; згадаємо лише основні їі напрями: виробництво, фінансування, бухгалтерський облік, кадри, безпека, реалізація продукції й послуг, маркетинг, реклама, інноваційна діяльність (розробки й дослідження). Останніми десятиліттями до них долучились піар- та інформаційні технології, постало питання про соціальну відповідальність бізнесу. Кожен із цих напрямів, зі свого боку, може диференціюватись, розщеплюватись, водночас синтезуються нові утворення (як-от піар виник на стику реклами, збуту й менеджменту). Завдяки розгалуженості і специфічній умотивованості інститут бізнесу здатен «прилаштувати до діла» більшість наукових відкриттів. Тому він порівняно легко перетворюється на полігон для випробування і впровадження наукових здобутків, відшукуючи можливості потенційно прибуткового застосування отриманих у процесі пізнання нових знань і розроблених на їх основі технологій. Переслідуючи власну прагматичну мету, він опредмечує світоглядні зміни, створюючи тим самим умови для втілення інновацій, а отже, сприяючи подовженню ланцюжка змін.

Висновки і пропозиції. Подібне «зрощення» пізнання й бізнесу не $\epsilon$ виключною цариною змін, але відзначається порівняно вищою віро- 
гідністю їх генерації; часи, коли Томас Едісон був унікальним поєднанням дослідника, винахідника й підприємця, давно минули, й зараз така різноплановість фактично є затребуваною рисою агента змін. Тож характерною для нинішньої епохи стає не тільки подальша диференціація професійної діяльності, а й універсалізація умінь тих, що, пафосно кажучи, «рухають прогрес».

\section{Список використаної літератури}

1. Бевзенко Л. Інтегративна концепція соціальної напруженості-методологія, концептуальна схема, прагматика. Соціологія: теорія, методи, маркетинг, 2018. № 3 (початок). С. 43-74; № 4 (закінчення). С. 73-104.

2. Куценко О. Майбутне соціології у світлі XIX Світового конгресу соціологів. Всеукраӥнський часопис «СВОС». (2019). URL: https://svoye.wordpress.com/2019/10/29/.

Martynyuk I. O., Sobolieva N. I. Social changes and agents of changes in the modern world: sociological reflections

The article is devoted to the problem of conceptualization of social agency in the modern world, definition of theoretical coordinates of sociological research of agents of social changes. The relevance of the development of the issue of agency is substantiated, the peculiarities of the realization of its various forms in the conditions of rapid social transformations and the search for effective ways to achieve social balance are analyzed. The representation of this issue in modern sociological discourse, in particular domestic, is considered.

There are some differences in the conceptualization of the concept of "agency" of representatives of different sociological trends and the lack of more or less established and agreed theoretical conclusions on the scientific definition of social agency. Based on the theoretical substantiation of the concept of "social agent", the key functions of change agents and the characteristics of change agents from the standpoint of activity parameters are identified. The turn of sociological theory towards the construction of models of interpretation of factors of practical life in the daily routine interaction of social actors at different levels marked a new perspective approach to identifying various combinations of dynamic components of social life as its formative circumstances and conditions.

Emphasis is placed on the importance in agent actions of both individuals and groups, strata, organizations and other communities of practices aimed at implementing or at least facilitating the achievement of social change. It is found that the practice as a social content, a kind of core of multilateral and multilevel subject-subject interaction, which in social realities is manifested in a variety of behavioral forms, is the embodiment, on the one hand, established by culture of value-normative elements, status -role features of the choice and application of behavioral patterns, on the other - the habitual work of the actor, a reflection of his motivational architecture. The combination of social and individual features in the structure of practice is one of the "crossroads" at which there is an interpenetration of established and different from it, innovative.

Key words: social development, social changes, agents of change, agents of influence, practices of social interaction. 